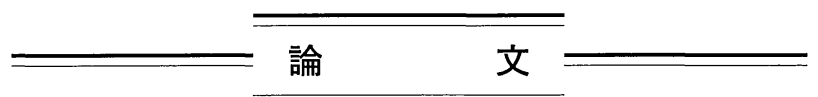

農業気象 (J. Agric. Meteorol.) 55 (2): 101-108, 1999

\title{
地気熱交換蒸留による回収水量推定に関する研究
}

\author{
阿部靖志・大槻恭一・神近牧男 \\ (鳥取大学乾燥地研究センター)
}

\section{Estimation of Water Quantity Recycled by Earth-Air Heat Exchange Distillation}

\author{
Yasushi Aвe, Kyoichi Otsuki and Makio KamichiкA \\ (Arid Land Research Center (ALRC), Tottori University,
1390, Hamasaka, Tottori, 680-0001 Japan
}

\begin{abstract}
The authors have developed a "Earth-Air Heat Exchange Distillation System" for collecting water from vapor originated in evapotranspiration. This system distills water from vapor by cooling the air in a greenhouse, using underground heat exchange pipes. It is similar to "Soil Heat ExchangerStorage Systems". A parameter for estimating the daily amount of collected water was investigated, based on heat and vapor budget of the heat exchange pipe. The results indicate that the daily amount of collected water is a linear function of the integrated surplus of air-soil temperature.

Key words : Earth-air heat exchange distillation system, Soil heat exchanger-storage systems, Vapor recycle.

キーワード : 地気熱交換蒸留, 地中熱交換温室, 水蒸気回収
\end{abstract}

\section{1.はじめに}

乾燥地農業においては水資源の確保・有効利用が最大 の課題である。そのため, 水資源の開発・節約に関して 多くの事業・研究が行なわれてきた。しかし，蒸発散に よって散逸した水を回収・利用するための研究はほとん ど行なわれていない。

蒸散によって大気中に放出される水は光合成によって 植物体に同化される水の千倍近い（Horie, 1986)。した がって蒸散によって失われる水を有効に循環利用できれ ば，水資源の不足から農耕不適地とされた場所む農地と して利用可能になる。

蒸散によって失われる水を大気中に散逸させることな く回収するためには，植物を密閉空間で育てる必要があ る。地中熱交換温室（Yamamoto, 1966）は，熱効率を 高めるために高い気密性が必要とされている（Yama-

1992 年 7 月 5 日 全国大会にて発表

1998 年 1 月 5 日 受付, 1999 年 1 月 13 日 受理 moto, 1977)。また密閉状態で温度調節が可能なため, その開発の比較的早い時期からガスコントロール可能 な植物栽培施設としての利用が提案されており (Yamamoto, 1967), 二酸化炭素施肥によるトマトの栽 培試験（Mori, 1977）が行なわれている。このように地 中熱交換温室は気密性が高いので，水蒸気の散逸を抑制 する施設としても充分な潜在力を有していると言える。 また地中熱交換温室では，日中に熱交換パイプ内で水蒸 気の凝結が起きることが知られており（Yamamoto, 1969)，この現象を利用することで水蒸気回収機能を容 易に付加できると考えられる。

以上の点に着目し, 筆者らは地中熱交換温室に水蒸気 回収機能を付加し（以後，一般の地中熱交換温室之区別 するため, 地気熱交換蒸留温室と呼ぶ)，基礎研究を実施 してきた（Isikawa et al., 1996)。レタスを栽培した地 気熱交換蒸留温室においては灌溉水の $30 \%$ を回収し, 回収水を灌溉に利用することで野外における栽培に比し て $40 \%$ の水量を節約できた（Kamichika et al., 
1993)。本報では地気熱交換蒸留温室における熱交換パ イプの回収水量予測のための变数の検討を行なう。

\section{2. 地中熱交換から地気熱交換蒸留へ}

地中熱交換温室は，地下に埋設したパイプに温室内空 気を循環させることで，土㙴一空気間で熱交換を行なわ せ，温度差によって蓄放熱を行なう太陽熱利用温室であ る（Takakura，1986）。昼間の蓄熱に注目すれば冷房 (Yamamoto, 1967; Santamouris et al., 1995) に, 夜 間の放熱に注目すれば暖房に利用できる（Yamamoto, 1977)。昼間の蓄熱時にはパイプ内では，送風された空 気が冷却される。この時空気が露点温度以下に冷却され れば，パイプ内では凝結が起きる (Yamamoto, 1969)。 この凝結水は, パイプ周辺土㙵の熱伝導率向上と夜間温 室内気温の上昇を担う顕熱放熱の割合を高めるために, 土壤中に排出される (Yamamoto, 1977)。

地中熱交換温室の熱交換パイプには，パイプ内で疑結 した水を地中に排出するために，排出用の穴があいたパ イプ，あるいは透水性素材のパイプが用いられている。 また地中熱交換温室においては，熱交換パイプに勾配を つける必要はない。一方地気熱交換蒸留温室において は，熱交換パイプには漏れの無い不透水性素材のパイプ を用い，自然流下による水回収のために勾配をつけてあ る (Fig. 1)。

\section{3. 実 験方法}

鳥取大学乾燥地研究センターのアリドトロン降雨遮断 大型ガラス温室内に Fig. 1 に示すような地気熱交換蒸 留温室を南北方向偪設し，1992 年 1 月 16 日から 2 月 22 日に実験を行なった。本研究に用いた地気熱交換 蒸留温室は, ビニール温室と地気熱交換蒸留装置の複合 体である。
ビニール温室は間口 $4.8 \mathrm{~m}$ ・高さ $2.4 \mathrm{~m}$ ・長さ $14.7 \mathrm{~m}$ の大きさで, 換気設備を備えていない。この温室内には 4 本の畦（幅 $80 \mathrm{~cm}$ ・高さ $20 \mathrm{~cm}$ ・畦間 $35 \mathrm{~cm}$ ）に株間 $40 \mathrm{~cm}$ で各畦に 28 株, 計 112 株のトマトを栽培した。 各畦中央には点滴ホースを地下 $5 \mathrm{~cm}$ に埋設し, 毎朝 9 時から 10 時にかけて充分に灌水した。

地気熱交換蒸留装置は地中への蓄放熱之水蒸気の凝結 を行なう装置で，地中に埋設した熱交換パイプとこれに 送風するためのファンおよび凝結水回収部によって構成 される。熱交換パイプには塩ビ管 VP 100 (内径 108 $\mathrm{mm}$ ・外径 $115 \mathrm{~mm}$ ）を接続し, 熱交換部の長さを 11.4 $\mathrm{m}$ としたあのを用いた。熱交換パイプ埋設深は熱交換部 の中央で $35 \mathrm{~cm}$, 水回収のためのパイプ勾配は $1 / 57$ （高低差 $20 \mathrm{~cm}$ ）とし, 北側（パイプ入口側）を浅く, 南 側（パイプ出口側）を深くした。実験終了後にパイプ出 口を塞いで水を満たし，水量に変化がないことを 10 日 間監視することで，接続部などに漏れがないことを確認 した。熱交換パイプの埋設位置は，西端の畦を除く各畦 の概ね中央直下で，埋設したパイプは 3 本である。熱交 換パイプへの送風には, 地上 $50 \mathrm{~cm}$ に立ち上げたパイ プ入口に接続したシロッコファンを用い，全実験期間を 通して常に送風を行なった（24 時間連続送風）。パイプ 出口中心部の風速は, 実験終了後に testo term 製ベー ン式ハンディタイプ風速計 GA-4400を用いて測定し, $4.6 \mathrm{~m} / \mathrm{s}$ という值を得た。凝結水回収部はパイプ出口が 突き出した地下室（壁面: ベニヤ板・深さ $1 \mathrm{~m} ・$ 幅 1 $\mathrm{m}$ ・奥行 $50 \mathrm{~cm}$ ）で, 凝結水之パイプ通過空気が出てく るパイプ出口直下にバケッを設置し，凝結水を回収し た。

観測項目は, 日回収水量, 温室内日射量, 東端のパイ プ出入口の通風乾湿球温度, パイプ埋設深地温である。 日回収水量は毎朝 9 時にメスシリンダーを用いて測定

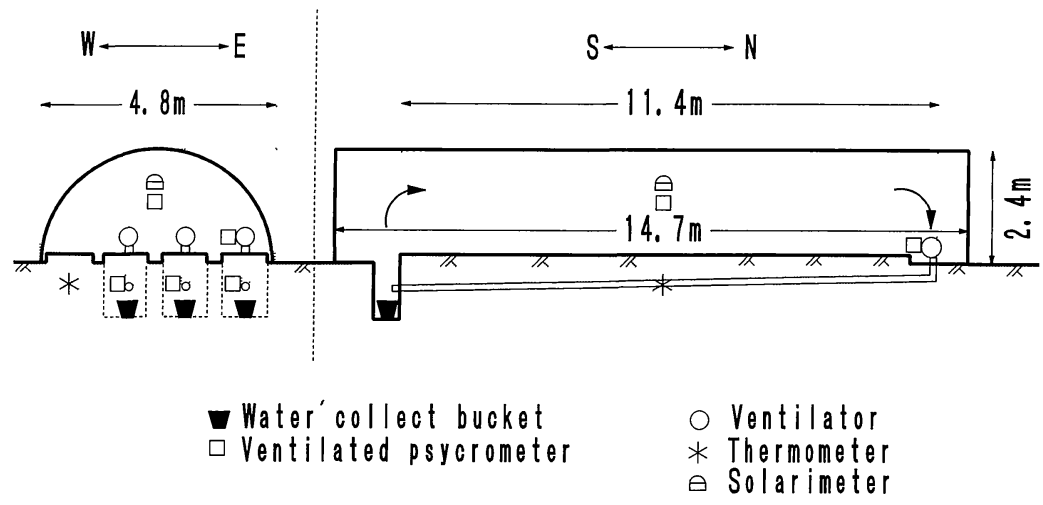

Fig. 1. Cross section of the "Earth-Air Heat Exchange Distillation System". 
した。このため，本研究の日界（観測日の区切り）は午 前 9 時である。温室内日射量は八ウス中央の地上 $2 \mathrm{~m}$ の位置に設置した日射計（英弘精機製エコー日射計 MS-61) で, 温度データは T-CC 熱電対温度計で観測 し，データロガー（英弘精機製 SOLACIII（MP-090） を用いて 10 分毎に記録した。パイプ埋設深地温は西端 の畦中央直下で観測した。この位置は最む近い熱交換パ イプから水平方向に約 $1 \mathrm{~m}$ 離れているので, 熱交換に伴 うパイプ周辺地温の日变化の影響を無視できる。

\section{4. 結果および考察}

実験の結果，水を回収できた日が 9 日あった。以後の 考察はこの 9 日について行なう。なお，日回収水量およ びパイプ通過空気の温湿度変化を用いた考察は, 東端の パイプ 1 本の結果を用いる。

Table 1 に水を回収できた 9 日の日回収水量 $C_{\mathrm{w}}$, 日射 量 $S_{\mathrm{d}}$, 温室内の気温 $T$, 絶対湿度 $Y$, 相対湿度 $R H$ を示 す。温室内日射量は 1 力所のみでの観測なのでフレーム の影の影響を除去できず, 観測值で温室内の日射量を代 表させることは不適切である。そこで日射量について は, フレームの影の影響が無い屋外日射量を併記する。 屋外日射量は乾燥地研究センターの観測露場で自動観測 されているデータで， 1 時間の積算值を毎正時に記録し たものである。日回収水量が多い日には絶対湿度および 気温が高く, 日射量が多い傾向がある。なお, 水が回収 できなかった日の天候は量雨天であり, 日射量は水を回 収できた日を越えることはなかった。

Fig. 2 にパイプ出入口の温湿度およびパイプ埋設深地 温の経時変化を示す。なお, 以後屯経時変化の図示は, 晴天日と曇天日が連続している 1 月 21 日から 1 月 22 日について行なう。パイプ出入口の気温は日中に上昇し 夜間に低下する日変化を示し, パイプ埋設深地温はほぼ
一定であった。このためパイプ出入口気温はパイプ埋設 深地温を, 日中は上回り, 夜間は下回った。パイプ出入 口絶対湿度の変化はパイプ出入口気温の変化に類似して いた。

パイプ入口の相対湿度は日中に最低值を示し，夜間は ほぼ 100\% で推移し，観測期間を通じて 90\%を下回る ことはまれであった。

パイプ出口の絶対湿度と気温は, パイプ入口の值と比 較して, 日中には低く, 夜間には高かった。以上の結果 は, パイプ内で, 潜熱・顕熱が日中には空気から奪われ， 夜間には空気に与えられることを示している。

\section{1 パイプ内水収支}

昼間パイプ内に送り込まれた湿り空気は，いくらかの 水蒸気を凝結によって失い，温室内に還流する。パイプ には漏れがないので, パイプ出入口の水蒸気量の差と風 量の積が, パイプ内における単位時間当たりの凝結量と 考えられる。これを式に表すと次のようになる。

$$
\begin{aligned}
D_{\mathrm{r}} & =V\left(Y_{\text {in }}-Y_{\text {out }}\right) \\
& =V \Delta Y
\end{aligned}
$$

$D_{\mathrm{r}}:$ 凝結速度 $[\mathrm{g} / \mathrm{s}]$

$V:$ 風量 $\left[\mathrm{m}^{3} / \mathrm{s}\right]$

$Y$ : 絶対湿度 $\left[\mathrm{g} / \mathrm{m}^{3}\right]$

$\Delta Y:$ パイプ出入口絶対湿度差

$$
\Delta Y=Y_{\text {in }}-Y_{\text {out }}
$$

添え字, in, out はそれぞれパイプの入口, 出口を示す パイプ内では, 凝結速度が正の時には凝結が, 負の時 には蒸発が起きている。風量は常時正なので, 凝結速度 の正負はパイプ出入口絶対湿度差に支配される。した がって, パイプ入口の絶対湿度がパイプ出口の值を上回 る日中には凝結が，両者の関係が逆転する夜間には蒸発

\begin{tabular}{|c|c|c|c|c|c|c|c|c|c|c|c|c|}
\hline \multirow{2}{*}{ Date } & \multirow{2}{*}{$\begin{array}{l}C_{\mathrm{w}} \\
{[\mathrm{g}]}\end{array}$} & \multicolumn{2}{|c|}{$S_{\mathrm{d}}\left[\mathrm{MJ} / \mathrm{m}^{2}\right]$} & \multicolumn{3}{|c|}{$T\left[{ }^{\circ} \mathrm{C}\right]$ EAHED } & \multicolumn{3}{|c|}{$Y\left[\mathrm{~g} / \mathrm{m}^{3}\right]$ EAHED } & \multicolumn{3}{|c|}{$R H[\%]$ EAHED } \\
\hline & & EAHED & ALRC & $\max$ & avg & $\min$ & $\max$ & avg & $\min$ & $\max$ & avg & $\min$ \\
\hline $01 / 16$ & 2,107 & 4.75 & 10.89 & 29.2 & 14.7 & 8.1 & 26.9 & 13.3 & 8.2 & 100 & 96.7 & 89.7 \\
\hline $01 / 21$ & 2,446 & 5.07 & 11.12 & 29.7 & 13.8 & 6.2 & 28.3 & 12.7 & 7.3 & 100 & 96.6 & 74.1 \\
\hline $01 / 22$ & 1,060 & 2.65 & 6.97 & 25.0 & 11.9 & 5.5 & 22.5 & 11.1 & 6.9 & 100 & 98.3 & 92.8 \\
\hline $01 / 26$ & 2,657 & 4.66 & 10.90 & 31.4 & 15.0 & 6.3 & 31.6 & 14.1 & 7.4 & 100 & 97.9 & 92.2 \\
\hline $01 / 27$ & 2,167 & 4.20 & 10.34 & 29.6 & 15.3 & 6.7 & 28.0 & 14.1 & 7.5 & 100 & 97.7 & 91.8 \\
\hline 02/09 & 209 & 2.54 & 6.16 & 21.3 & 8.7 & 2.9 & 18.4 & 9.1 & 5.9 & 100 & 99.7 & 95.8 \\
\hline $02 / 10$ & 2,577 & 4.21 & 11.09 & 30.4 & 14.3 & 6.6 & 29.7 & 13.4 & 7.6 & 100 & 99.0 & 92.8 \\
\hline $02 / 21$ & 105 & 2.28 & 5.60 & 23.2 & 8.9 & 5.1 & 20.6 & 9.1 & 6.8 & 100 & 99.7 & 96.9 \\
\hline $02 / 22$ & 18 & 2.40 & 5.85 & 25.0 & 8.7 & 3.6 & 22.1 & 9.1 & 6.2 & 100 & 99.9 & 94.2 \\
\hline
\end{tabular}
が起きている (Fig. 2)。これは日中に熱交換パイプ内で

Table 1 Climatological conditions during the experimental season (16. Jan.-22. Feb. 1992).

$C_{\mathrm{w}}$, collected water; $S_{\mathrm{d}}$, Total short wave radiation; $T$, air temperature; $Y$, absolute humidity; $R H$, relative humidity. Subscripts max avg min stands for maximum, average and minimum values. ALRC means that the data were measured at the observation field of "Arid Land Research Center". EAHED means that the data were measured inside the "Earth-Air Heat Exchange Distillation System". 


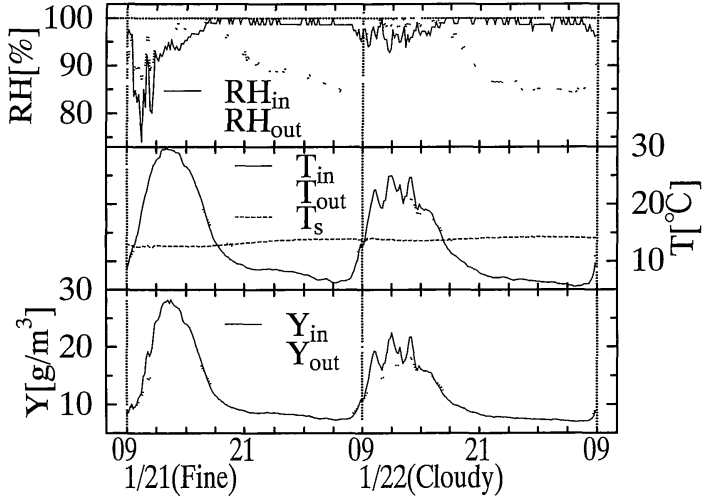

Fig. 2. Temporal change of relative humidity $(R H)$, temperature $(T)$ and absolute humidity $(Y)$ (in: Entrance of heat exchange pipe, out: exit of the pipe). $T_{\mathrm{s}}$ is soil temperature.

凝結した水が完全に回収されず，夜間に蒸発しているこ とを示していると考えられる。また，パイプ内表面に付 着した水が完全に蒸発せずにパイプ内に残留することが あれば，(1）式を 1 日について時間積分してあ日回収水 量は求まらない。そこで, パイプ内表面に付着・残留す る水量の最大值（以後, パイプ内損失水量と呼ぶ）は一 定であると考え，これを越えて凝結した分が回収される と考えた。1 日にパイプ内で凝結する水量は凝結速度が 正の時だけを時間積分すれば求まる。そこで，正の值の みを採用する関数 $p$ と, 関数 $p$ を 1 日について時間積分 する関数 $\boldsymbol{P}$ を定義する（(2)(3) 式)。

$$
\begin{cases}p(\chi)=\chi & (\chi \geq 0) \\ p(\chi)=0 & (\chi<0)\end{cases}
$$

$\chi:$ 任意の変数

$$
\boldsymbol{P}(\chi)=\int_{0}^{86400} p(\chi) d t
$$

$t$ : 時間 $[\mathrm{s}]$

以上の定義関数を用いてパイプ内における一日の凝結 水量を表すと次式のようになる。

$$
D_{\mathrm{w}}=P\left(D_{\mathrm{r}}\right)
$$

$D_{\mathrm{w}}$ : 日凝結水量 $[\mathrm{g} / \mathrm{day}]$

本研究に抢いては $V$ は未知の值であるが, 常時一定 の值なので定数として取り扱える。したがって（4）式は 次のように書き換えられる。

$$
D_{\mathrm{w}}=V P(\Delta Y)
$$

日回収水量はパイプ内損失水量を越えた凝結水量なの

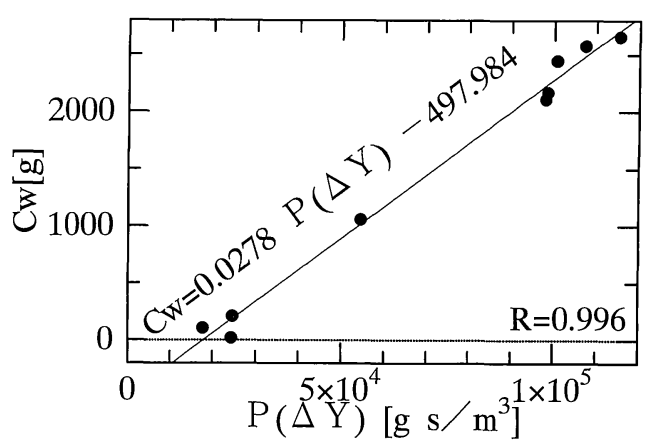

Fig. 3. The daily amount of recycled water $\left(C_{\mathrm{w}}\right)$ as a function of integrated absolute humidity measured near the pipe $(P(\Delta Y))$.

$$
\begin{aligned}
P(\Delta Y)= & \int_{0}^{86400} p(\Delta Y) d t \\
& \begin{cases}p(\Delta Y)=0 & \left(Y_{\text {in }} \leq Y_{\text {out }}\right) \\
p(\Delta Y)=Y_{\text {in }}-Y_{\text {out }} & \left(Y_{\text {in }}>Y_{\text {out }}\right)\end{cases}
\end{aligned}
$$

で，次式で求まる。

$$
\begin{cases}C_{\mathrm{w}}=D_{\mathrm{w}}-L & \left(D_{\mathrm{w}} \geq 0\right) \\ C_{\mathrm{w}}=0 & \left(D_{\mathrm{w}}<0\right)\end{cases}
$$

$C_{\mathrm{w}}$ : 日回収水量 $[\mathrm{g} / \mathrm{day}]$

$L$ : パイプ内損失水量 $[\mathrm{g}]$

（5）式を（6）式に代入して（7）式を得る。

$$
\begin{cases}C_{\mathrm{w}}=V P(\Delta Y)-L & (P(\Delta Y) \geq 0) \\ C_{\mathrm{w}}=0 & (P(\Delta Y)<0)\end{cases}
$$

関数 $P$ が時間積分関数であるため, $P(\Delta Y)$ を求めるに は $\Delta Y$ を時間関数で表現する必要がある。本研究におい ては観測值から求めた $\Delta Y$ を直線補完した関数を用い, $P(\Delta Y)$ を求めた。すなおち本研究においては, $\Delta Y$ が正 の時間帯について, 台形則で $\Delta Y$ を時間積分した值が $P(\Delta Y)$ である。Fig. 3 に $P(\Delta Y)$ と日回収水量の関係 を示す。両者の関係について 1 次の回帰分析を行ない,

（8）式を得た。

$$
C_{\mathrm{w}}=0.0278 P(\Delta Y)-497.984 \quad R=0.996
$$

（7）式との比較から, 係数 $(=0.0278)$ が風量を, 切 片（=497.984）がパイプ内損失水量を示していると考 えられる。すなわち, 風量をパイプ断面積で除した平均 風速は約 $3 \mathrm{~m} / \mathrm{s}$ であり, パイプ内損失水量は約 $500 \mathrm{~g}$ だったと言える。以上のようにして得られたパイプ内平 均風速は, 前述のパイプ中心風速の測定值の約 $2 / 3$ (65.9\%) であり，管内の平均流速としては妥当な值を 示している。よって, 以後の議論では（8）式の係数を風 量として用いる。 


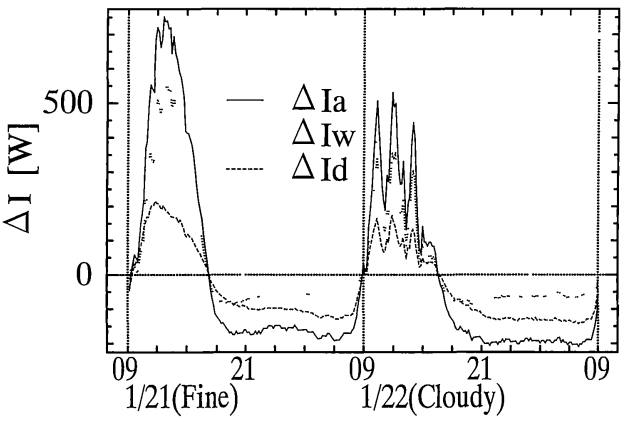

Fig. 4. The heat budget of the air passing through the pipe as a function of time ( $\Delta I_{\mathrm{a}}$ : enthalpy, $\Delta I_{\mathrm{d}}$ : sensible heat, $\Delta I_{\mathrm{w}}$ : latent heat).

\section{2 パイプ内熱収支}

パイプ内でのパイプ通過空気の熱交換量は以下の式で 示される。

$$
\begin{aligned}
& \Delta I_{\mathrm{a}}=V\left(I_{\mathrm{a}_{\text {in }}}-I_{\mathrm{a}_{\text {out }}}\right) / v \\
& \Delta I_{\mathrm{d}}=V\left(I_{\mathrm{d}_{\text {in }}}-I_{\mathrm{d}_{\text {out }}}\right) / v \\
& \Delta I_{\mathrm{w}}=V\left(I_{\mathrm{w}_{\text {in }}}-I_{\mathrm{w}_{\text {out }}}\right) / v
\end{aligned}
$$

$$
\begin{aligned}
& \Delta I_{\mathrm{a}} \text { : パイプ内全熱交換量 }[\mathrm{W}] \\
& \Delta I_{\mathrm{d}} \text { : パイプ内顕熱交換量 }[\mathrm{W}] \\
& \Delta I_{\mathrm{w}} \text { : パイプ内潜熱交換量 }[\mathrm{W}] \\
& I_{\mathrm{a}} \text { : 全熱量 }\left[\mathrm{J} / \mathrm{kg}^{\prime}\right] \\
& I_{\mathrm{a}}=I_{\mathrm{d}}+I_{\mathrm{w}} \\
& I_{\mathrm{d}} \text { : 顕熱量 }\left[\mathrm{J} / \mathrm{kg}^{\prime}\right] \\
& I_{\mathrm{d}}=1005 T_{\mathrm{d}} \\
& T_{\mathrm{d}} \text { : 湿り空気の乾球温度 }\left[{ }^{\circ} \mathrm{C}\right] \\
& I_{\mathrm{w}} \quad \text { : 潜熱量 }\left[\mathrm{J} / \mathrm{kg}^{\prime}\right] \\
& I_{\mathrm{w}}=1000\left(2501+1.846 T_{\mathrm{d}}\right) x \\
& x \text { : 混合比 }\left[\mathrm{kg} / \mathrm{kg}^{\prime}\right] \\
& v \text { : 比容積 }\left[\mathrm{m}^{3} / \mathrm{kg}^{\prime}\right]
\end{aligned}
$$

Fig. 4 にパイプ通過空気の熱交換量の経時変化を示す。 パイプ通過空気の全熱交換に占める潜熱交換の割合は, パイプ内で疑結が起きる日中は約 $2 / 3(64.8 \%)$, 蒸発 が起きる夜間は約 1/3（33.4\%）である。このように, 地気熱交換蒸留の熱交換パイプにおける 1 日の熱収支 は，蓄熱は潜熱に偏り，放熱は顕熱に偏っており，熱交 換が温室内気温に及ぼす影響は, 日中の降温が少なく夜 間の昇温が多いと言える。

\section{3 日回収水量と地気温差の関係}

以上のようにパイプ出入口の温湿度データから水回収 量が求まる。しかしパイプ出入口の温湿度デー夕は施設 を運用することで得られるので, 施設設置前の日回収水 量推定には不向きである。そこで, パイプ出入口の温湿
度デー夕を用いずに，日回収水量を説明する変数を考え る。

凝結はパイプ内での潜熱交換の結果である。すなわ ち, パイプ内での凝結水量を求めるには, パイプ内での 潜熱交換について考えればよい。パイプ内での熱交換は 強制対流熱伝達である。そこで対流熱伝達を記述する ニュートンの冷却の法則を応用する方法を検討する。 ニュートンの冷却の法則は次式で与えられる。

$$
q=h S\left(T_{0}-T_{\infty}\right)
$$

$q$ : 熱交換量 $[\mathrm{W}]$

$h$ : 熱伝達率 $\left[\mathbf{W} /\left(\mathrm{m}^{2} \mathbf{K}\right)\right]$

$S$ : 熱交換面積 $\left[\mathrm{m}^{2}\right]$

$T_{0}$ : 熱交換面温度 $[\mathrm{K}]$

$T_{\infty}$ : 熱交換面加 充分遠い流体の温度 $[\mathrm{K}]$

ニュートンの冷却の法則は, 固体-流体間の熱交換量が 温度差と熱交換面積に比例することを示している。当 初, ニュートンの泠却の法則は顕熱交換のみに適用され ていたが,ルイスの関係 (Lewis, 1922) によって全熱交 換の記述にも適用されるようになってきた。ルイスの関 係は空気線図上の等エンタルピ線が等湿球温度線に平行 之みなせる範囲で成り立つので, 本研究や空気調和の分 野が扱う常温・常圧下での全熱交換の記述にニュートン の冷却の法則を適用可能である。全熱交換をニュートン の冷却の法則で記述し始めた頃には顕熱交換の場合之区 別するために，(12）式の $h$ を $U$ などの異なる文字に置 き換え，総括熱伝達率と呼んでいた。しかし最近では両 者を区別せず，どちらの場合あ単に熱伝達率と呼ぶよう になってきている(JSME, 1985 など)。以上の経過を踏 まえ, 本研究においても全熱交換を（12）式の形で記述 する。

パイプ内での熱交換量を求めるために（12）式を変形 すると以下のようになる。

$$
\Delta I_{\mathrm{a}}=\left(S_{\mathrm{pi}} / X_{\mathrm{e}}\right) \int_{0}^{X_{\mathrm{e}}} h_{\mathrm{p} X}\left(T_{0 X}-T_{\mathrm{a} X}\right) d X
$$

$S_{\mathrm{p} 1}$ : パイプ内表面積 $\left[\mathrm{m}^{2}\right]$

$h_{\mathrm{p} X}: X$ におけるパイプ内の熱伝達率 $\left[\mathrm{W} /\left(\mathrm{m}^{2} \mathrm{~K}\right)\right]$

$T_{0 X}: X$ におけるパイプ内表面温度 $[\mathrm{K}]$

$T_{\mathrm{aX}}: X$ におけるパイプ中心気温 $[\mathrm{K}]$

$X$ : パイプ入ロからの距離 $[\mathrm{m}]$

$X_{\mathrm{e}}$ : パイプ長 $[\mathrm{m}]$

パイプ長さ方向に微小分割した各部位においては（12） 式が成り立つが, パイプ中心気温と内表面温度は熱交換 の影響で連続的に変化し, 熱伝達率も厳密にはパイプ内 での凹凸などにより部位によって変化するため，このよ 
うな積分が必要になる。（13）式を解くためには熱伝達 率, パイプ内表面温度, パイプ中心気温をパイプ入口か らの距離の関数で表現しなくてはならないが，これは困 難である。そこで Yamamoto（1977）はパイプ外表面 とパイプ通過空気の温度差の平均值と平均熱伝達率を用 いた（14）式を用いた。なお，パイプ内表面温度ではな くパイプ外表面温度を用いているのは測定の都合であ り, 式の意味としては同じである。

$$
\Delta I_{\mathrm{a}}=h_{\mathrm{pi}} S_{\mathrm{pi}}\left(T_{0 \mathrm{~m}}-T_{\mathrm{am}}\right)
$$

$h_{\mathrm{pi}}$ : パイプ内での平均熱伝達率 $\left[\mathrm{W} /\left(\mathrm{m}^{2} \mathrm{~K}\right)\right]$

$T_{0 \mathrm{~m}}$ : パイプ外表面温度の平均値 $[\mathrm{K}]$

$T_{\mathrm{am}}$ : パイプ中心気温の平均值 $[\mathrm{K}]$

（14）式の温度の平均值は，パイプ入口から出口に至る 2 点の值の平均値が用いられたが，そのような值を施設 の運用前に得ることは難しい。そこで本研究では，(14） 式の $T_{0 \mathrm{~m}}$ と $T_{\mathrm{am}}$ を両者を代表していると考えられる別 の值に置き換えることを考える。

熱交換パイプ流入直前のパイプ中心気温は $T_{\mathrm{nn}}$ であ り, 通過距離の増加に伴って $T_{\mathrm{s}}$ に漸近すると考えられ る。また，パイプ内表面温度はパイプ入口付近で $T_{\mathrm{m}}$ に 最む近く, 通過距離の増加に伴って $T_{\mathrm{s}}$ に漸近するが，こ の漸近はパイプ中心気温のそれより早い。よって $T_{\mathrm{in}}$ と $T_{\mathrm{s}}$ の間に $T_{\mathrm{am}}$ と $T_{0 \mathrm{~m}}$ が存在し, $T_{\mathrm{am}}$ は $T_{\mathrm{in}} に, T_{0 \mathrm{~m}}$ は $T_{\mathrm{s}}$ に近い。これは $T_{\mathrm{am}}$ と $T_{0 \mathrm{~m}}$ の両方を $T_{\mathrm{n}}$ と $T_{\mathrm{s}}$ の荷重平 均で表現できることを示している。ここで $T_{\mathrm{am}}$ と $T_{0 \mathrm{~m}}$ を それぞれ以下のような $T_{\mathrm{in}}$ と $T_{\mathrm{s}}$ の荷重平均で表現する。

$$
\begin{aligned}
& T_{\text {om }}=\frac{T_{\text {in }}+A T_{\mathrm{s}}}{1+A} \\
& T_{\mathrm{am}}=\frac{T_{\mathrm{in}}+B T_{\mathrm{s}}}{1+B}
\end{aligned}
$$

$A, B:$ 荷重（0 以上）

これを用いて（14）式の温度差の項を表現すると以下の ようになる。

$$
\begin{aligned}
& T_{0 \mathrm{~m}}-T_{\mathrm{am}}=D\left(T_{\mathrm{s}}-T_{\mathrm{in}}\right) \\
& D=\frac{A-B}{(1+A)(1+B)}
\end{aligned}
$$

上式の荷重 $A, B$ の決定手法に関しては今後の研究を待 たねばならない。しかし既に多くの研究が，地温の推定 (Hirota et al., 1995 など) と温室内の温度環境（Tachibana, 1980 など）に関して行なわれており,これらの成 果に若干の研究を積み重㸚ることで, パイプ埋設深地温 $T_{\mathrm{s}}$ およびパイプ入口気温 $T_{\text {in }}$ は容易に求まるようになる と考える。そこで本研究では（14）式の $T_{0 \mathrm{~m}}$ を $T_{s}$ で, $T_{\text {am }}$ を $T_{\text {in }}$ で置き換えた。これを式に示すと以下のよう になる。

$$
\Delta I_{\mathrm{a}}=h_{\mathrm{pr}} S_{\mathrm{pi}}\left(T_{\mathrm{s}}-T_{\mathrm{in}}\right)
$$

$h_{\mathrm{pr}}$ : 置換の影響を補正した $h_{\mathrm{pi}}\left[\mathrm{W} /\left(\mathrm{m}^{2} \mathrm{~K}\right)\right]$

$$
h_{\mathrm{pr}}=D h_{\mathrm{pi}}
$$

$T_{\mathrm{s}}$ : パイプから充分離れたパイプ埋設深地温 $[\mathrm{K}]$

$T_{\mathrm{in}}$ : パイプ入口気温 $[\mathrm{K}]$

潜熱交換量は全熱交換量から顕熱交換量を差し引いた 值なので，（15）式からパイプ内顕熱交換量を差し引け ばパイプ内潜熱交換量が求まる。パイプ内顕熱交換量の 式は Yamamoto and Inoue（1971）により明らかにさ れている（(16）式)。

$$
\Delta I_{\mathrm{d}}=V C_{\mathrm{v}}\left(T_{\mathrm{n}}-T_{\mathrm{s}}\right)\left\{1-\exp \left(-\kappa X_{\mathrm{e}}\right)\right\}
$$

$C_{\mathrm{v}}:$ 空気の体積熱容量 $\left[\mathrm{J} /\left(\mathrm{m}^{3} \mathrm{~K}\right)\right]$

$\kappa:$ パイプ通過気温低下係数 $\left[\mathrm{m}^{-1}\right]$

（15）式から（16）式を差し引いて求まるパイプ内潜熱 交換量を凝結潜熱で除せば，我々が必要とするパイプ内 凝結量が求まる ((17) 式)。

$$
\begin{aligned}
D_{\mathrm{r}} & =\left(\Delta I_{\mathrm{a}}-\Delta I_{\mathrm{d}}\right) / l \\
& =\left(T_{\mathrm{n}}-T_{\mathrm{s}}\right)\left[V C_{\mathrm{v}}\left\{1-\exp \left(-\kappa X_{\mathrm{e}}\right)\right\}-h_{\mathrm{pr}} S_{\mathrm{pi}}\right] / l \\
& =a \Delta T \\
l \quad: & \text { 凝結潜熱 }[\mathrm{kJ} / \mathrm{kg}] \\
a \quad: & \text { 係数 }[\mathrm{kg} /(\mathrm{Ks})] \\
& \quad a=\left[V C_{\mathrm{v}}\left\{1-\exp \left(-\kappa X_{\mathrm{e}}\right)\right\}-h_{\mathrm{pr}} S_{\mathrm{pi}}\right] / l \\
\Delta T: & \text { 地気温差 }[\mathrm{K}] \\
& \Delta T=T_{\mathrm{in}}-T_{\mathrm{s}}
\end{aligned}
$$

（17）式の係数 $a$ はパイプの長さ, 径, 形状, 通過風速, パイプおよび周辺土壌の熱的特性などに支配されるが, 施設の運用が始まればほぼ一定の值と考えられるので, 定数として取り扱う。（17）式を基に日回収水量を求め る式を考えると，(1）式加ら（7）式への変換と同様の 操作を行えばよいので，(18）式のようになる。

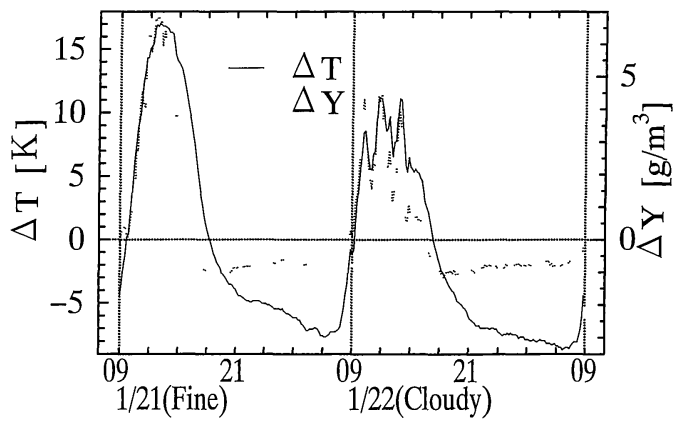

Fig. 5. Temporal change of $\Delta T$ and $\Delta Y$ $\left(\Delta T=T_{\text {in }}-T_{\mathrm{s}} ; \Delta Y=Y_{\text {in }}-Y_{\text {out }}\right)$. 


$$
\begin{cases}C_{\mathrm{w}}=a P(\Delta T)-L & (P(\Delta T) \geqq 0) \\ C_{\mathrm{w}}=0 & (P(\Delta T)<0)\end{cases}
$$

（18）式の独立変数は $P(\Delta T)$ で，これと同じ形式の（7） 式の独立変数は $P(\Delta Y)$ である。そこで両式の独立変数 を算定する際に必要となる地気温差とパイプ出入口絶対 湿度差の経時変化を比較する (Fig. 5)。地気温差はパイ プ出入口絶対湿度差の増加にはほぼ追随しているが，減 少には遅れる傾向がある。これは熱交換により生じるパ イプ内表面温度とパイプ埋設深地温の差の影響だと思わ れる。また両者の夜間の変化は大きく異なるが，これは パイプ内表面に付着・残留していた水の蒸発に伴って蒸 発面が減少し，パイプ通過空気の熱交換に占める顕熱の 割合が増加するためだと思われる。以上のように両者の 間には若干の相違点があるものの, 日回収水量の算定に 用いる時間帯に関しては良く似た変化を示している。し たがって（18）式を日回収水量の算定に用いることが可 能であると考える。

次に, 本研究で得られたデー夕を用いて（18）式を検 証する。（18）式は日回収水量が $P(\Delta T)$ に比例するこ とを示しているので, $P(\Delta T)$ と日回収水量の関係が 1 次関数になっていればよい。 $P(\Delta T)$ は得られたデー夕 から地気温差を計算し, これを $P(\Delta Y)$ の計算と同様に 直線補完して決定した関数を，(2）式と（3）式の定義 関数で処理して求めた。こうして得られた $P(\Delta T)$ と日 回収水量の関係を Fig. 6 に示す。両者の関係は 1 次関 数で表現できると思われるので， 1 次の回帰分析を行な い（19）式を得た。

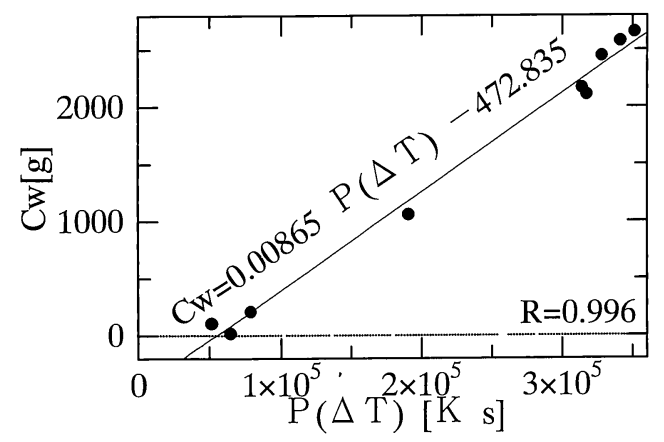

Fig. 6. The daily amount of recycled water $\left(C_{\mathrm{w}}\right)$ as a function of integrated temperature measured near the pipe $(P(\Delta T))$.

$$
\begin{aligned}
P(\Delta T)= & \int_{0}^{86400} p(\Delta T) d t \\
& \begin{cases}p(\Delta T)=0 & \left(T_{\text {in }} \leq T_{\text {out }}\right) \\
p(\Delta T)=T_{\text {in }}-T_{\text {out }} & \left(T_{\text {in }}>T_{\text {out }}\right)\end{cases}
\end{aligned}
$$

$$
C_{\mathrm{w}}=0.00865 P(\Delta T)-472.835 \quad R=0.996
$$

（19）式に示したように $P(\Delta T)$ と日回収水量は相関 が高く, これは（18）式の妥当性を示していると考える ことができる。したがって, 日回収水量を $P(\Delta T)$ を用 いて推定できるといえる。

\section{5. おわりに}

筆者らは本研究において, 植物が放出する水蒸気を回 収する地気熱交換蒸留温室を提案し，この回収水量の推 定に有用な変数を検討した。地気熱交換蒸留温室は地中 熱交換温室の熱交換パイプに, 凝結した水の回収機能を 付加したあので, 地中への蓄熱によって温度調節を行な うと同時に，蒸発散によって失われる水蒸気を回収する システムである。

本研究では, 地気熱交換蒸留温室の熱交換パイプ内で の凝結を水蒸気収支之熱収支の観点から検討し, パイプ 入口気温がパイプ埋設深地温を上回る時間帯について両 者の温度差を時間積分した值である $P(\Delta T)$ の 1 次関数 で, 日回収水量を表現できることを示した。 $P(\Delta T)$ と日 回収水量は正の関係なので, $P(\Delta T)$ が大きいほど日回 収水量は多くなる。ある深さの地温は一定期間の気温の 平均值に等しく, 温室内気温は温室外気温に似た变化を 示すと考えることができるので，気温の日較差が大きい 地域ほど $P(\Delta T)$ が大きく, 回収水量が多くなると言え る。この情報は地気熱交換蒸留温室を設置する地域の選 定に有用である。また $P(\Delta T)$ は, 気候值などから推定 可能な值だと考えられ，推定手法を確立すれば施設設置 前の回収水量評価に有効である。今後, なお一層の研究 が必要であると考える。

\section{謝 辞}

本研究の実施において, 鳥取大学乾燥地研究センター 乾地環境部門自然環境分野の学生一同に多大なる協力を 頂きました。また, 山口大学の早川誠而教授, 鳥取大学 の吉田勲教授には暖かなご支援を頂きました。記して感 謝します。

\section{References}

Hirota, T., Fukumoto, M., Shirooka, R. and Muramatsu, K., 1995: Simple method of estimating daily mean soil temperature by using the forcerestore model. J. Agric. Meteorol., 51 (3), 269-277.

Horie, T., 1986: Transpiration. In Editing Committee of "Technical Terms of Agricultural Meteorology", The Society of Agricultural Meteorology of Japan, Editor: Technical Terms of Agricultural 
Meteorology. The Society of Agricultural Meteorology of Japan, Tokyo, p. 143 (堀江 武, 1986: 蒸 散. 日本農業気象学会農業気象用語編集委員会編: 農 業気象用語解説集, 日本農業気象学会, 東京, $p$. 143).

Isikawa, M., Otsuki, K. and Kamichika, M., 1996: Distillation system using solar heat and temperature difference between soil and air. Jour. JSIDRE, 64 (3), 13-18.

JSME, 1985: JSME Mechanical Engineer's Handbook B. Applications B 8: Heat Exchangers, Air Conditioning and Refrigeration. JSME, Tokyo, 74 pp.

Kamichika, M., Yamamoto, T., Otsuki, K. and Abe, Y., 1993: Recycling use of irrigated water by earth-air heat exchange distillation. J. Agric. Meteorol., 48 (5), 667-669.

Lewis, W.K., 1922: The evaporation of a liquid into a gas. Trans. ASME., 44, 325-340.

Mori, T., 1977: Application of earth-air heat exchange greenhouse for winter period tomato cultivation. Agric. Hortic., 52, 41-45（森 俊人, 1977: 地中熱交換方式による冬期温室卜マト栽培の実用性. 農業及び園芸，52，41-45).

Santamouris, M., Mihalakakou, G., Balaras, C.A., Argiriou, A., Asimakopoulos, D. and Vallindras, M., 1995: Use of buried pipes for energy conservation in cooling of agricultural greenhouses. Solar Energy, 55 (2), 111-124.

Takakura, T., 1986: Solar greenhouse. In Editing Committee of "Technical Terms of Agricultural Meteorology, Editor: Technical Terms of Agricultural Meteorology. The Society of Agricultural Meteorology of Japan). The Society of Agricultural Meteorology of Japan, Tokyo, p. 187 (高倉 直,
1986: 太陽熱利用温室. 日本農業気象学会農業気象用 語編集委員会編: 農業気像用語解説集. 日本農業気象 学会, 東京, p. 187).

Tachibana, K., 1980: Radiation and heat budget in greenhouse -Derivation of equations on heat flux and temperature-. J. Agric. Meteorol., 36 (1), 2535.

Yamamoto, Y., 1966: An application of earth-air heat exchange. J. Agric. Meteorol., 22 (2), 77-79.

Yamamoto, Y., 1967: The earth-air heat exchange and an example of its application. Electric Agronomy Laboratory Report, 8, 79-87 (山本雄二郎, 1967: 地中一空気熱交換とその応用例, 農電研究所報, 8 , 79-87).

Yamamoto, Y., 1969: Studies on the earth-air heat exchange greenhouse I. Temperature and thermal characteristics of the earth-air heat exchange greenhouse. Electric Agronomy Laboratory Report, 10, 27-39 (山本雄二郎, 1969: 地中一空気熱交換温室 の研究 (I) 地中一空気熱交換ハウスの温度および熱特 性. 農電研究所報, 10, 27-39).

Yamamoto, Y. and Inoue, K., 1971: Studies on the earth-air heat exchange greenhouse II. Influence of wind velocity of the air passing through the pipe as well as of the types of pipe on the cooling effects. Electric Agronomy Laboratory Report, 11, 1-6（山 本雄二郎・井上莞需, 1971: 地中一空気熱交換温室の 研究 (II) パイプ通過空気の風速およびパイプの種類 が冷却効果に及ぼす影響. 農電研究所報, 11, 1-6).

Yamamoto, Y., 1977: Studies on the greenhouse heating by the underground heat exchange system. CRIEPI Report, 476007, 1-67 (山本雄二郎, 1977: 地中熱交換方式による栽培用温室の暖房に関する研 究. 電力中央研究所報告, 476007, 1-67). 